\title{
Alternatives for Additional Spent Fuel Storage in South Korea
}

\section{J. Kang}

As its at-reactor (AR) spent fuel storage pools become saturated, South Korea will have to increase interim storage capacity for spent fuel. This study estimates South Korea's additional spent fuel storage requirements through the year 2030, and then evaluates one measure with the potential for reducing requirements for new away-from reactor (AFR) storage: transshipment of spent fuel between nuclear power plant (NPP) sites. Such transshipment, if implemented, could make a significant contribution to relieving requirements for additional spent fuel storage. If intersite transshipment cannot be implemented due to concerns about transport of spent fuel or for other reasons, on-site dry storage would be the next most cost effective alternative.

\section{INTRODUCTION}

All spent nuclear fuel discharged from South Korea's PWRs and CANDU reactors is stored in at-reactor (AR) spent fuel storage pools, with the exception of a small quantity of CANDU spent fuel stored at a dry storage facility. ${ }^{1}$ Given that an underground repository for the permanent disposal of spent fuel will not be available for at least three decades, ${ }^{2}$ South Korea will have to develop additional interim storage capacity to accommodate the spent fuel as the AR spent fuel stores become saturated. Although there was an early plan for a centralized away-from-reactor (AFR) interim storage facility for the spent fuel, ${ }^{3}$ it has been delayed until 2016, ${ }^{4}$ due to public opposition in the early 1990s. As a result, much more temporary storage for much longer time periods will be required than was originally anticipated.

Received 23 March 1999; accepted 15 October 2002.

J. Kang, Ph.D., Nuclear Engineering, 101-1005 Cheonggu Apt., Jamwon-dong, Scochogu, Seoul 137-030, South Korea. E-mail: jmkang55@hotmail.com 
With this background, this study estimates requirements for additional spent fuel storage capacity for spent fuel from PWRs and CANDU reactors in South Korea through the year 2030. ${ }^{5}$ Then, it evaluates how these requirements could be reduced by intersite transshipment of spent fuel between NPP sites if such transfer is implemented.

\section{PROJECTION OF TOTAL ELECTRICITY AND NUCLEAR CAPACITY}

Future spent fuel generation from PWRs and CANDU reactors will depend on projections of installed nuclear capacity, which in turn will depend on the total electricity generation and on the share of nuclear power for that generation over the period of time being studied. For this study, projections are made out to 2030 , the time at which an underground repository for permanent disposal of spent fuel could become available.

\section{Projections of Total Electricity Generation through the Year 2030}

Recently, the South Korean government estimated total electricity generation and installed nuclear capacity for the years $1998-2015 .^{6}$ In order to estimate total electricity generation for the years 2016-2030, this study uses a logistic curve fitting method $^{7}$ to estimate per capita electricity generation for the years 2016-2030. Then, total electricity generation can be calculated by multiplying per capita electricity generation by estimated population.

Table 1 shows total electricity generation, population, and per capita electricity generation in South Korea, which are used as base data in estimating the projections of per capita electricity generation for the years 2016-2030. The year 1995 is assumed as the base year in the projections of per capita electricity generation.

Table 1: Total electricity generation, population and per capita electricity generation in South Korea.*

\begin{tabular}{llll}
\hline Year & $\begin{array}{l}\text { Total electricity generation } \\
\text { (TWh) }\end{array}$ & $\begin{array}{l}\text { Population } \\
\text { (million) }\end{array}$ & $\begin{array}{l}\text { Per capita electricity } \\
\text { (MWh) }\end{array}$ \\
\hline 1995 & 184.7 & 45.09 & 4.1 \\
2005 & 328.6 & 49.12 & 6.7 \\
2015 & 429.7 & 51.68 & 8.3 \\
\hline
\end{tabular}

Note: In 2030, South Korea's population will be approximately 52.74 million.

* The Fourth Long-term Power Development Plan (1998-2015), MOCIE, South Korea, August 1998 (Korean). Major Statistics of Korean Economy, National Statistical Office (NSO), South Korea, September 1997 (Korean). KOSIS-DB, NSO, South Korea (Korean). 


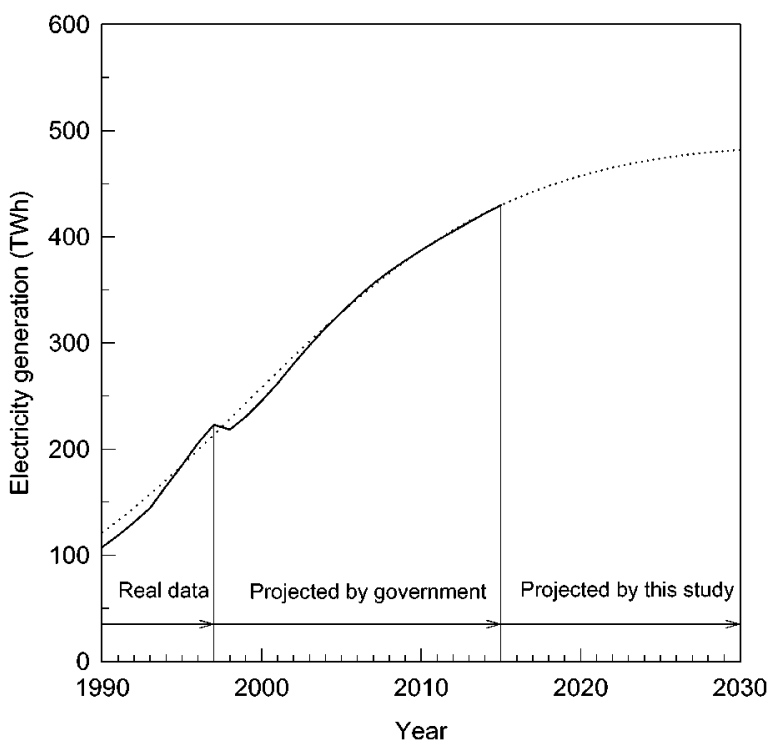

Figure 1: Total electricity generation in South Korea (1990-2030).

The derived asymptote, i.e., $\mathrm{E}_{\infty}$, for the annual per capita electricity generation is 9.3 MWh around the year 2045, about $1 \mathrm{MWh}$ higher than 8.2 MWh of the average per capita electricity of the OECD countries in $1995 .^{8}$

Total electricity generation can then be obtained by multiplying per capita electricity generation by the population projection over the period of time. The derived projections of total electricity generation for the years 2016-2030 are shown in Figure 1. Figure 1 also shows the real historical data up to 1997 and projections by the South Korean government to 2015, plotted as a solid line. Total electricity generation in 2030 is estimated to be approximately $480 \mathrm{TWh}$.

\section{Projections of Installed Nuclear Capacity through the Year $\mathbf{2 0 3 0}$}

Projections of nuclear power over the next three decades will be affected by a number of factors, e.g., economic growth, public acceptance, and so on. This study assumes two scenario projections for the years 2016-2030. One is a "reference scenario," based upon the assumption of sustained development of nuclear power. The other is a "low growth scenario," based upon the assumption that no new nuclear power plants are built after 2016. 
Table 2: South Korea's long-term nuclear power supply plan.*

\begin{tabular}{llcl}
\hline Unit & Type & Capacity (MWe) & Operation \\
\hline Wolsong 3 & CANDU & 700 & 1998.7 \\
Ulchin 3 & PWR & 1,000 & 1998.8 \\
Wolsong 4 & CANDU & 700 & 1998.9 \\
Ulchin 4 & PWR & 1,000 & 1999.12 \\
Yonggwang 5 & PWR & 1,000 & 2002.5 \\
Yonggwang 6 & PWR & 1,000 & 2002.12 \\
Ulchin 5 & PWR & 1,000 & 2004.6 \\
Ulchin 6 & PWR & 1,000 & 2005.6 \\
Unit 1 & PWR & 1,000 & 2008.9 \\
Unit 2 & PWR & 1,000 & 2009.9 \\
Unit 3 & PWR & 1,000 & 2009.9 \\
Unit 4 & PWR & 1,000 & 2010.9 \\
APR1400a & Advanced PWR & 1,400 & 2010.9 \\
APR1400 & Advanced PWR & 1,400 & 2011.9 \\
APR1400 & Advanced PWR & 1,400 & 2014.6 \\
APR1400 & Advanced PWR & 1,400 & 2015.6 \\
\hline
\end{tabular}

aAdvanced Power Reactor 1400

* The First Power Supply Plan (2002-2015), MOCIE, South Korea, August 2002 (Korean).

For installed nuclear capacity before 2001, real historical data is adopted. For the years 2002-2015, projections by the South Korean government are adopted. This long-term nuclear power supply plan for the years 2002-2015 is given in Table 2.

\section{Reference Scenario}

For the reference scenario, projections of the share of nuclear power may be estimated by a similar method used to project per capita electricity generation. The essential assumption is that the nuclear fraction will approach $50 \%$ of total electricity consumption asymptotically by 2045. This is shown in Table 3 and Figure 2. In Figure 2, a solid line for the years 2016-2030 shows the projections of installed nuclear capacity for the reference scenario. The installed nuclear capacity will be $32.0 \mathrm{GWe}$ in 2030 . The specifics of reactor deployment in the years 2016-2030 are explained in the following.

This study assumes that the specific reactor types deployed in the years 2016-2030 will be based on the long-term nuclear power plan of the South Korean government. According to the 1995 Long-term Power Development Plan $^{9}$ and the Comprehensive Nuclear Energy Promotion Plan, ${ }^{10}$ PWRs would remain as the main reactor type, with no further deployment of CANDU reactors after completion of four reactors in 1999. The study assumes that PWRs of 1.0 GWe and 1.4 GWe will be mainly deployed for the years 2016-2030, except that a new CANDU reactor of 0.7 GWe will replace a decommissioned CANDU 
Table 3: Installed nuclear capacity in South Korea through the year 2030 (reference scenario).

\begin{tabular}{|c|c|c|c|c|c|c|c|}
\hline $\begin{array}{l}\text { End of } \\
\text { year }\end{array}$ & $\begin{array}{l}\text { New } \\
\text { PWR } \\
\text { (MWe) }\end{array}$ & $\begin{array}{l}\text { New } \\
\text { CANDU } \\
\text { (MWe) }\end{array}$ & $\begin{array}{l}\text { Decom. }^{a} \\
\text { PWR } \\
\text { (MWe) }\end{array}$ & $\begin{array}{l}\text { Decom. } \\
\text { CANDU } \\
\text { (MWe) }\end{array}$ & $\begin{array}{l}\text { Cumul. } \\
\text { PWR } \\
\text { (MWe) }\end{array}$ & $\begin{array}{l}\text { Cumul. } \\
\text { CANDU } \\
\text { (MWe) }\end{array}$ & $\begin{array}{l}\text { Cumul. } \\
\text { total } \\
\text { (MWe) }\end{array}$ \\
\hline $\begin{array}{l}1978 \\
1979 \\
1980 \\
1981 \\
1982\end{array}$ & 587 & & & & $\begin{array}{l}587 \\
587 \\
587 \\
587 \\
587\end{array}$ & & $\begin{array}{l}587 \\
587 \\
587 \\
587 \\
587\end{array}$ \\
\hline $\begin{array}{l}1983 \\
1984\end{array}$ & 650 & 679 & & & $\begin{array}{l}1,237 \\
1.237\end{array}$ & $\begin{array}{l}679 \\
679\end{array}$ & $\begin{array}{l}1,916 \\
1916\end{array}$ \\
\hline 1985 & 950 & & & & 2,187 & 679 & 2,866 \\
\hline 1986 & 1,900 & & & & 4,087 & 679 & 4,766 \\
\hline 1987 & 950 & & & & 5,037 & 679 & 5,716 \\
\hline 1988 & 950 & & & & 5,987 & 679 & 6,666 \\
\hline 1989 & 950 & & & & 6,937 & 679 & 7,616 \\
\hline $\begin{array}{l}1990 \\
1991\end{array}$ & & & & & $\begin{array}{l}6,937 \\
6,937\end{array}$ & $\begin{array}{l}679 \\
679\end{array}$ & $\begin{array}{l}7,616 \\
7,616\end{array}$ \\
\hline 1992 & & & & & 6,937 & 679 & 7,616 \\
\hline 1993 & & & & & 6,937 & 679 & 7,616 \\
\hline 1994 & & & & & 6,937 & 679 & 7,616 \\
\hline 1995 & 1,000 & & & & 7,937 & 679 & 8,616 \\
\hline 1996 & 1,000 & & & & 8,937 & 679 & 9,616 \\
\hline 1997 & & 700 & & & 8,937 & 1,379 & 10,316 \\
\hline 1998 & 1,000 & 700 & & & 9,937 & 2,079 & 12,016 \\
\hline 1999 & 1,000 & 700 & & & 10,937 & 2,779 & 13,716 \\
\hline 2000 & & & & & 10,937 & 2,779 & 13,716 \\
\hline 2001 & & & & & 10,937 & 2,779 & 13,716 \\
\hline 2002 & 2,000 & & & & 12,937 & 2,779 & 15,716 \\
\hline 2003 & & & & & 12,937 & 2,779 & 15,716 \\
\hline 2004 & 1,000 & & & & 13,973 & 2,779 & 16,716 \\
\hline 2005 & 1,000 & & & & 14,937 & 2,779 & 17,716 \\
\hline 2006 & & & & & 14,937 & 2,779 & 17,716 \\
\hline 2007 & & & & & 14,937 & 2,779 & 17,716 \\
\hline 2008 & 1,000 & & & & 15,937 & 2,779 & 18,716 \\
\hline 2009 & 2,000 & & & & 17,937 & 2,779 & 20,716 \\
\hline 2010 & 2,400 & & & & 20,337 & 2,779 & 23,116 \\
\hline 2011 & 1,400 & & & & 21,737 & 2,779 & 24,516 \\
\hline 2012 & & & & & 21,737 & 2,779 & 24,516 \\
\hline 2013 & & & & 679 & 21,737 & 2,100 & 23,837 \\
\hline 2014 & 1,400 & & & & 23,137 & 2,100 & 25,237 \\
\hline 2015 & 1,400 & & & & 24,537 & 2,100 & 26,637 \\
\hline 2016 & 1,400 & & & & 25,937 & 2,100 & 28,037 \\
\hline 2017 & & 700 & & & 26,937 & 2,800 & 28,737 \\
\hline 2018 & & & 587 & & 25,350 & 2,800 & 28,150 \\
\hline 2019 & 1,000 & & & & 26,350 & 2,800 & 29,150 \\
\hline 2020 & & & & & 26,350 & 2,800 & 29,150 \\
\hline 2021 & & & & & 26,350 & 2,800 & 29,150 \\
\hline 2022 & 1,000 & & & & 27,350 & 2,800 & 30,150 \\
\hline 2023 & & & 650 & & 26,700 & 2,800 & 29,500 \\
\hline 2024 & 1,000 & & & & 27,700 & 2,800 & 30,500 \\
\hline 2025 & 1,400 & & 950 & & 28,150 & 2,800 & 30,950 \\
\hline 2026 & 2,000 & & 1,900 & & 28,250 & 2,800 & 31,050 \\
\hline 2027 & 1,400 & & 950 & & 28,700 & 2,800 & 31,500 \\
\hline 2028 & 1,000 & & 950 & & 28,750 & 2,800 & 31,550 \\
\hline 2029 & 1,400 & & 950 & & 29,200 & 2,800 & 32,000 \\
\hline & & & & & 29,200 & 2,800 & 32,000 \\
\hline
\end{tabular}




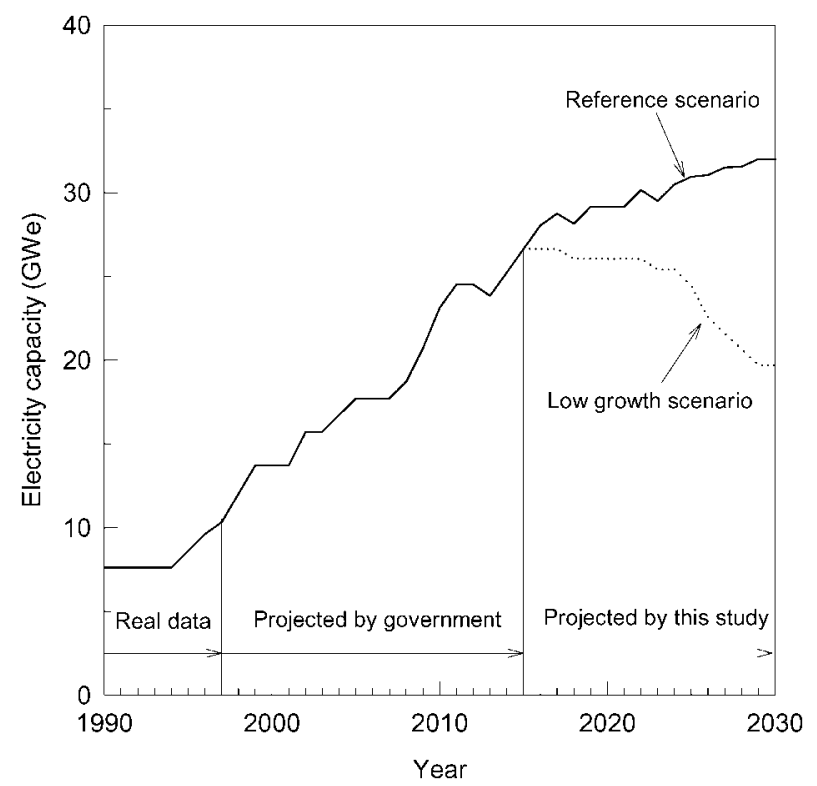

Figure 2: Installed nuclear capacity in South Korea (1990-2030).

reactor in 2017. Then, projections of installed nuclear capacity are adjusted by combination of the deployment of PWRs of $1.0 \mathrm{GWe}$ and $1.4 \mathrm{GWe}$ and a CANDU reactor of 0.7 GWe for the years 2016-2030. The lifetime of all reactors is assumed to be 40 years, although design lifetime of APR1400 is 60 years, ${ }^{11}$ except for the first CANDU reactor, which is assumed to be 30 years. $^{12}$

\section{Low Growth Scenario}

The low growth scenario assumes that no new reactors will be deployed after 2016. The projection of installed nuclear capacity in the years 2016-2030 for this scenario is shown by the dotted line in Figure 2. The installed nuclear capacity would be 19.7 GWe in 2030 .

\section{PROJECTIONS OF SPENT FUEL GENERATION}

\section{South Korea's Spent Fuel Inventory}

By end of 2001, 5,406 metric tons of initial heavy metal (tHM) of spent fuels had been discharged from PWRs and CANDU reactors, and stored in 
Table 4: Inventory of spent fuels in South Korea at end of 2001.*

\begin{tabular}{llll}
\hline $\begin{array}{l}\text { Kori site } \\
\text { (PWR spent fuel, } \\
\text { tHM) }\end{array}$ & $\begin{array}{l}\text { Yonggwang site } \\
\text { (PWR spent fuel, } \\
\text { tHM) }\end{array}$ & $\begin{array}{l}\text { Ulchin site } \\
\text { (PWR spent fuel, } \\
\text { tHM) }\end{array}$ & $\begin{array}{l}\text { Wolsong site } \\
\text { (CANDU spent fuel, } \\
\text { tHM) }\end{array}$ \\
\hline 1,246 & 819 & 632 & 2,709 \\
\hline
\end{tabular}

*2001 Annual Report for Radiation Management in the Nuclear Power Plants in Korea, Korea Electric Power Corporation (KEPCO), South Korea, 2002 (Korean).

AR spent fuel storage facilities at four NPP sites in South Korea: 2,697 tHM of spent PWR fuels and 2,709 tHM of spent CANDU fuels. Table 4 shows the details of the inventory of spent fuels in South Korea. Currently, there are four NPP sites in South Korea: Kori, Yonggwang, and Ulchin site for PWRs, and Wolsong for CANDU reactors. Figure 3 shows their locations.

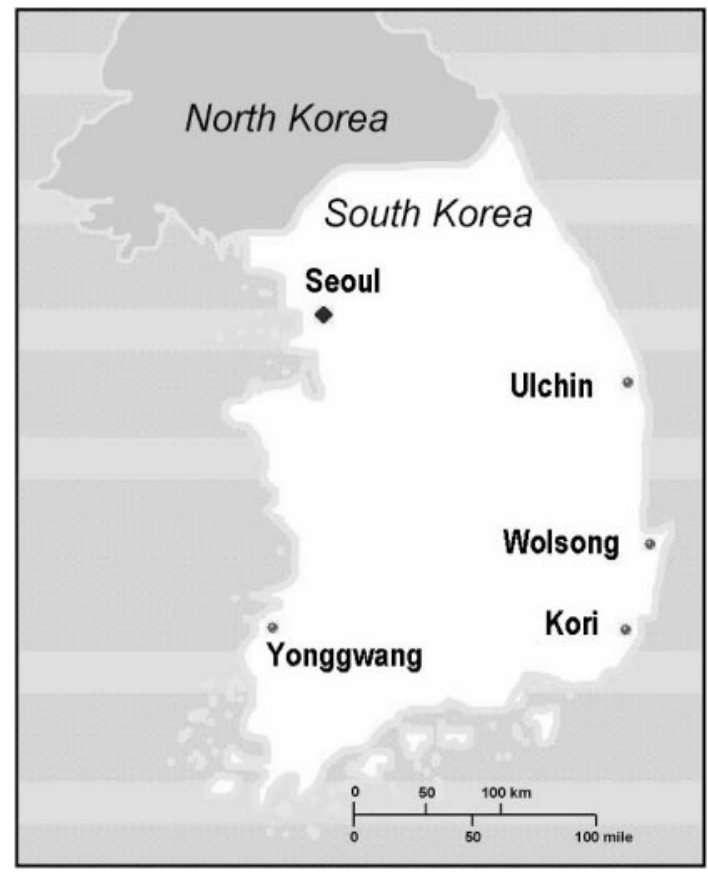

Figure 3: NPP sites in South Korea. 
Table 5: Characteristics of typical PWR and CANDU fuel assemblies.*

\begin{tabular}{llc}
\hline Characteristics & PWR & CANDU \\
\hline Fuel rod array & $17 \times 17$ & N/A \\
Fuel rods per assembly & 264 & 37 \\
Assembly total weight, kg & 657.9 & 23.6 \\
Uranium per assembly, kg & 461.4 & 18.8 \\
UO ${ }_{2}$ per assembly, kg & 523.4 & 21.3 \\
\hline *J. W. Roddy et al., Physical and Decay Characteristics of Commercial LWR Spent Fuel, \\
ORNL/TM-9591/V1, October 1985. K. M. Wasywich, Characteristics of Used CANDU Fuel Rele- \\
vant to the Canadian Nuclear Fuel Waste Management Program, AECL-10463, COG-91-340, \\
May 1993.
\end{tabular}

\section{South Korea's Nuclear Fuel Supply Plan}

Projections of spent fuel generation from the reactors largely depend on the nuclear fuel supply plan. According to the current plan, more than $60 \%$ of PWRs will be charged with the Vantage $5 \mathrm{H}$ (V5H) fuel assembly of Westinghouse for the years 1997-2009, and all PWRs will be charged with the Korean Next Generation (KNG) fuel assembly after year 2010. ${ }^{13}$ The V5H fuel assembly has the same fuel rod array structure and contains nearly the same amount of uranium (461.5 kg per assembly $)^{14}$ as that for the typical PWR fuel assembly described in Table 5. Average burn-up of spent V5H fuel is anticipated to be $43,000-48,000 \mathrm{MWd} / \mathrm{tHM}$, and that of spent $\mathrm{KNG}$ fuel to be $55,000 \mathrm{MWd} / \mathrm{tHM}^{15}$ For CANDU reactors, the CANDU Flexible Fuel (CANFLEX) is planned to be loaded from around the year 2005. ${ }^{16}$ The CANFLEX fuel, which could use 1.2 weight-percent of enriched uranium, has a much higher burn-up potential than conventional CANDU fuel, approximately 21,600 MWd/tHM. ${ }^{17}$ The amount of uranium contained in the CANFLEX fuel $(18.6 \mathrm{~kg} \text { per assembly })^{18}$ is nearly the same as that of the typical CANDU fuel assembly.

\section{Spent Fuel Generation for Reference Scenario}

Engineering advances in fuel integrity and improved fuel management techniques likely will result in extended burn-up compared to the current burn-up. Based on the nuclear fuel supply plan, this study assumes two burn-up cases for projections of spent fuel discharges through the year 2030. One is "current burn-up case," based upon the current burn-up levels out to 2030. The other is "extended burn-up case," assuming increased discharged burn-up levels for PWRs and for CANDU reactors from 2010 and 2005, respectively. 


\section{Reference Scenario with Current Burn-up Case}

Based on the projections of the installed nuclear capacity in Table 3, spent fuel discharges from PWRs and CANDU reactors may be estimated through the year 2030 for the current burn-up case. The historical inventories of spent fuel, given in Table 4, are combined with these projections to provide estimates of cumulative arisings of spent fuel. The estimates assume a once-through nuclear fuel cycle, with no fuel reprocessing.

Average discharged burn-up levels for South Korean commercial spent nuclear fuel in 1996 were around 43,000 MWd/tHM and 7,100 MWd/tHM for spent PWR and CANDU fuel, respectively. ${ }^{19}$ The current burn-up case assumes these burn-up figures during the years 1997-2030. Estimation of annual spent fuel discharges is described in the footnote ${ }^{20}$ Currently, average thermal efficiency levels for South Korean commercial spent nuclear fuel are around $34.9 \%$ and $33.7 \%$ for PWRs and CANDU reactors, respectively. ${ }^{21}$ Constant capacity factors of $80 \%$ are assumed during the years 1997-2030 for PWRs and CANDU reactors.

Figure 4 shows projections of annual spent fuel generation for the reference scenario with current burn-up. Figure 5 and Table 6 show the projections of spent fuel generation in terms of cumulative inventory. These results include spent fuel discharged from decommissioned reactors. Approximately $43 \%$ of the cumulative spent fuel discharged through the year 2030 will be from CANDU reactors, although the electricity capacity of CANDU reactors will be only approximately $8 \%$ of total nuclear capacity in $20300^{22}$

\section{Scenario with Extended Burn-up}

Based on the nuclear fuel supply plan in South Korea, the extended burnup case assumes that the average burn-up of spent PWR fuel will increase to $55,000 \mathrm{MWd} / \mathrm{tHM}$ after 2010 , and that of spent CANDU fuel to $21,600 \mathrm{MWd} / \mathrm{tHM}$ after 2005. Figure 6 shows projections of annual spent fuel generation for the reference scenario with extended burn-up. Figure 7 and Table 7 show the corresponding projections of cumulative spent fuel generation. The extended burn-up case shows a reduction of cumulative spent PWR fuel by approximately $15 \%$ through 2030 , compared to the current burnup case, and of cumulative spent CANDU fuel generation by approximately $47 \%$. 


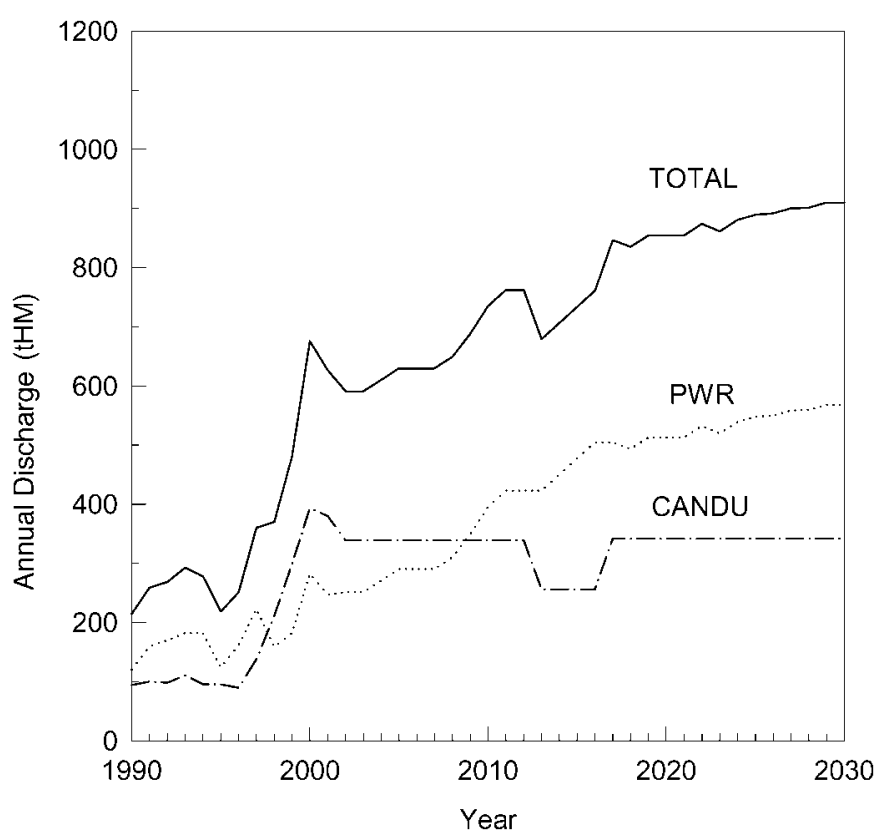

Figure 4: Annual spent fuel generation in South Korea (1990-2030) (reference scenario with current burn-up).

\section{Spent Fuel Generation for Low Growth Scenario}

The low growth scenario assumes that there are no new reactors deployed after 2016, except for a new CANDU reactor that replaces a decommissioned one in 2017. Table 8 shows the projections of cumulative spent fuel generation for the low growth scenario with current and extended burn-up. The low growth scenario shows reductions of cumulative spent PWR fuel generation to 2030 of approximately $10 \%$ and $9 \%$ for current and extended burn-up cases, respectively, compared to the corresponding reference scenario.

\section{PROJECTIONS OF SPENT FUEL STORAGE CAPACITY}

\section{Status of At-Reactor (AR) Spent Fuel Storage Capacity}

All spent fuel discharged from PWRs and CANDU reactors has been stored in AR spent fuel storage pools, or, for some CANDU spent fuel at a dry storage facility, at the reactor site. Table 9 shows the status of AR spent fuel storage 


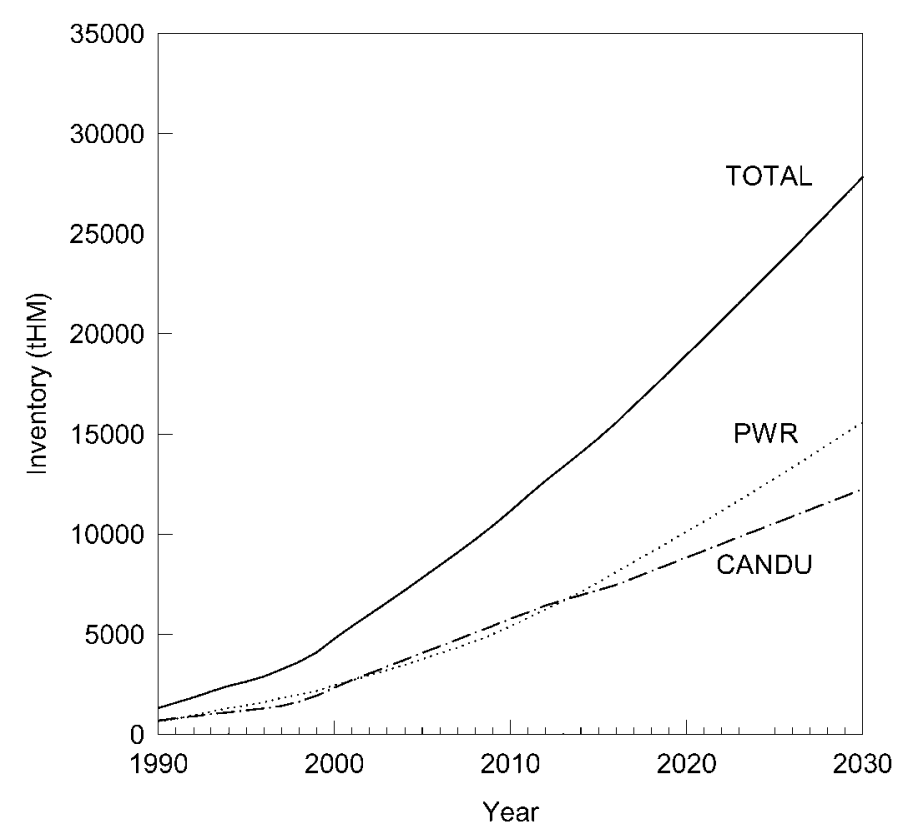

Figure 5: Cumulative inventory of spent fuel generation in South Korea (1990-2030) (reference scenario with current burn-up).

capacities at the four NPP sites in South Korea. The pool capacity of each planned PWR is assumed to be $461 \mathrm{tHM},{ }^{23}$ the same capacity as that of Yonggwang 5 and 6 (Korean Standard Nuclear Power Plants), and that of the new planned CANDU reactor to be 579 tHM.

\section{Additional Spent Fuel Storage Capacity for Reference Scenario}

Additional spent fuel storage requirements are then estimated for two cases: (1) no intersite transshipment allowed, and (2) intersite transshipment allowed. In both cases, it is assumed that no spent fuel will be reprocessed or sent out of country in the indicated time period.

Reference Scenario with No Intersite Transshipments

The no intersite transshipment case assumes that spent fuel transfer between sites is not allowed, but that transfer between NPPs at the same site is allowed. A reactor whose pool is full may ship its discharged fuel assemblies to 
Table 6: Cumulative spent fuel generation in South Korea (1990-2030) (reference scenario with current burn-up).

\begin{tabular}{lccl}
\hline Type & By 2010 (tHM) & By 2020 (tHM) & By 2030 (tHM) \\
\hline PWR & 5,400 & 10,120 & 15,580 \\
CANDU & 5,760 & 8,830 & 12,250 \\
Total & 17,160 & 18,950 & 27,830 \\
\hline
\end{tabular}

another reactor pool that has more capacity. For spent fuel to be discharged from decommissioned reactors, five years are assumed for the movement of all spent fuel from pools to other storage pools at the same site after plant shutdown. ${ }^{24}$

Table 10 shows the years when Kori, Yonggwang, Ulchin, and Wolsong sites are expected to saturate their spent fuel storage capacities for the reference scenario with no intersite transshipment for both burn-up cases. In the extended

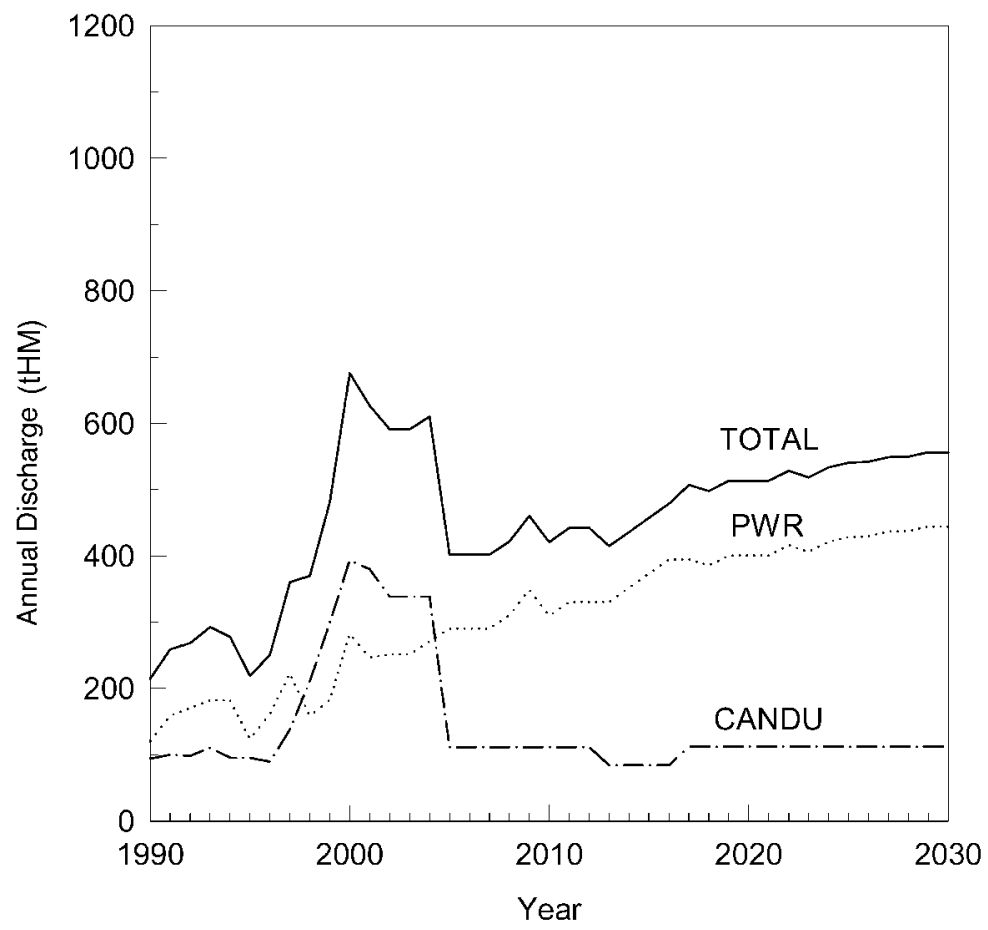

Figure 6: Annual spent fuel generation in South Korea (1990-2030) (reference scenario with extended burn-up). 


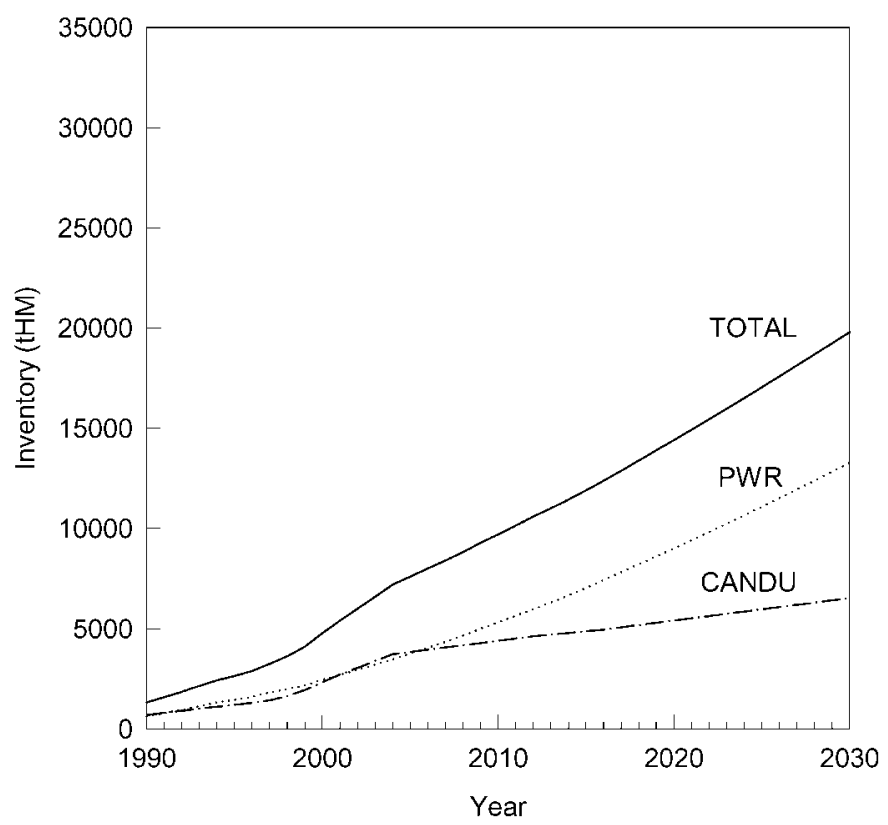

Figure 7: Cumulative inventory of spent fuel generation in South Korea (1990-2030) (reference scenario with extended burn-up).

burn-up case, the saturation times of pool capacities are prolonged by just a few years because of late commencement times of extended burn-up for PWRs and CANDU reactors, compared to the current burn-up case.

Table 11 shows the cumulative additional storage capacity required for the reference scenario with no intersite transshipment for both burn-up cases. The extended burn-up case shows a reduction of additional spent fuel storage capacity requirements of approximately $29 \%$ and $67 \%$ by 2030 for PWRs and CANDU reactors, respectively, compared to the current burn-up case.

Table 7: Cumulative spent fuel generation in South Korea (1990-2030) (reference scenario with extended burn-up case).

\begin{tabular}{llcc}
\hline Type & By 2010 (tHM) & By 2020 (tHM) & By 2030 (tHM) \\
\hline PWR & 5,310 & 9,010 & 13,270 \\
CANDU & 4,400 & 5,400 & 6,530 \\
Total & 9,710 & 14,410 & 19,800 \\
\hline
\end{tabular}


Table 8: Cumulative spent fuel generation in South Korea (1990-2030) (low growth scenario).

\begin{tabular}{lccc}
\hline Type & By 2010 (tHM) & By 2020 (tHM) & By 2030 (tHM) \\
\hline Current burn-up case & & & \\
PWR & 5,400 & 9,950 & 14,040 \\
CANDU & 5,760 & 8,490 & 11,050 \\
$\quad$ Total & 17,160 & 18,440 & 25,100 \\
Extended burn-up case & & & \\
PWR & 5,310 & 8,890 & 12,070 \\
CANDU & 4,400 & 5,290 & 6,130 \\
Total & 9,710 & 14,160 & 18,200 \\
\hline
\end{tabular}

Table 9: Status of AR spent nuclear fuel storage capacity in South Korea.*

\begin{tabular}{|c|c|c|c|c|}
\hline Unit & Type & $\begin{array}{l}\text { Installed } \\
\text { capacity } \\
\text { (MWe) }\end{array}$ & Condition & $\begin{array}{l}\text { Management } \\
\text { pool capacity } \\
(\mathrm{tHM})^{a}\end{array}$ \\
\hline Kori-1 & PWR & 587 & In operation & 151 \\
\hline Kori-2 & PWR & 650 & In operation & 328 \\
\hline Kori-3 & PWR & 950 & In operation & $1,189^{\circ}$ \\
\hline Kori-4 & PWR & 950 & In operation & $652^{b}$ \\
\hline Yonggwang-1 & PWR & 950 & In operation & $652^{b}$ \\
\hline Yonggwang-2 & PWR & 950 & In operation & $652^{b}$ \\
\hline Yonggwang-3 & PWR & 1,000 & In operation & $383^{c}$ \\
\hline Yonggwang-4 & PWR & 1,000 & In operation & $383^{c}$ \\
\hline Yonggwang-5 & PWR & 1,000 & Under construction & $461^{c}$ \\
\hline Yonggwang-6 & PWR & 1,000 & Under construction & $461^{c}$ \\
\hline Ulchin-1 & PWR & 950 & In operation & $744^{b}$ \\
\hline Ulchin-2 & PWR & 950 & In operation & $448^{b}$ \\
\hline Ulchin-3 & PWR & 1,000 & In operation & $383^{c}$ \\
\hline Ulchin-4 & PWR & 1,000 & Under construction & $383^{c}$ \\
\hline Ulchin-5 & PWR & 1,000 & Planned & $461^{c}$ \\
\hline Ulchin-6 & PWR & 1,000 & Planned & $461^{c}$ \\
\hline Wolsong-1 & CANDU & 679 & In operation & 643 \\
\hline Wolsong-2 & CANDU & 700 & In operation & 579 \\
\hline Wolsong-3 & CANDU & 700 & In operation & 579 \\
\hline Wolsong-4 & CANDU & 700 & Under construction & $579(+1,436)^{d}$ \\
\hline \multicolumn{5}{|c|}{ 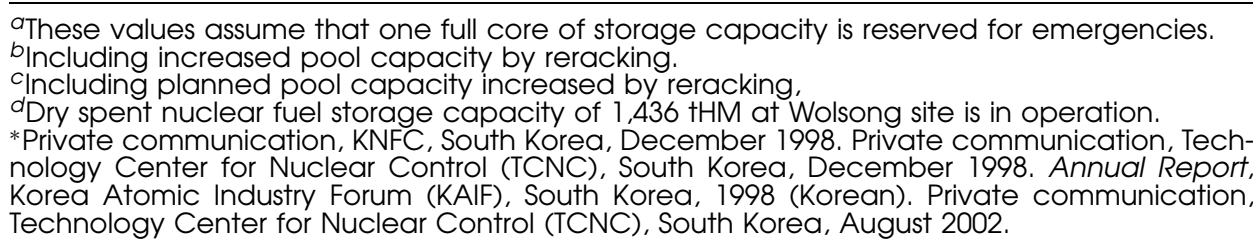 } \\
\hline
\end{tabular}


Table 10: Years for NPP sites to saturate their spent fuel storage capacities (reference scenario with no intersite transshipment).

\begin{tabular}{lll}
\hline Site & $\begin{array}{l}\text { Current burn-up case } \\
\text { (Year) }\end{array}$ & $\begin{array}{l}\text { Extended burn-up case } \\
\text { (Year) }\end{array}$ \\
\hline Kori & 2019 & 2021 \\
Yonggwang & 2019 & 2022 \\
Ulchin & 2021 & 2024 \\
Wolsong & 2004 & 2004 \\
SV & - & - \\
\hline
\end{tabular}

\section{Reference Scenario with Intersite Transshipments Allowed}

The intersite transshipment case assumes that spent fuel transfer is allowed between NPP sites of the same reactor type. Table 12 shows the cumulative additional storage capacity for the reference scenario with intersite transshipment for both burn-up cases. If intersite transshipment is allowed, even for the current burn-up case, no additional spent PWR fuel storage capacity will be needed to the year 2029 .

\section{Additional Spent Fuel Storage Capacity for Low Growth Scenario}

For the low growth scenario with no intersite transshipment, the poolsaturation times at NPP sites and cumulative additional storage capacity required will be unchanged from those for the reference scenario, as given in Table 10 and Table 11. With intersite transshipment, the pool-saturation times are shortened and the cumulative additional storage capacities are increased, compared to those for the reference scenario, because of no further increase of pool capacity for PWRs after 2016. However, even in this case, there will be no need of additional spent PWR fuel storage capacity by 2023 and by 2027 for the current burn-up case and the extended burn-up case, respectively.

Table 11: Cumulative additional storage capacity required in South Korea (reference scenario with no intersite transshipment).

\begin{tabular}{lrrr}
\hline Type & By 2010 (tHM) & By 2020 (tHM) & By 2030 (tHM) \\
\hline Current burn-up case & & & \\
PWR & 0 & 50 & 4,100 \\
CANDU & 1,950 & 5,180 & 8,590 \\
Total & 1,950 & 5,230 & 12,690 \\
Extended burn-up case & 0 & 0 & 2,930 \\
PWR & 580 & 1,750 & 2,870 \\
CANDU & 580 & 1,750 & 5,800 \\
Total & & & \\
\hline
\end{tabular}


Table 12: Cumulative additional storage capacity required in South Korea (reference scenario with intersite transshipment).

\begin{tabular}{lrrr}
\hline Type & By 2010 (tHM) & By $\mathbf{2 0 2 0}$ (tHM) & By 2030 (tHM) \\
\hline Current burn-up case & & & \\
PWR & 0 & 0 & 1,060 \\
CANDU & 1,950 & 5,180 & 8,590 \\
Total & 1,950 & 5,780 & 9,650 \\
Extended burn-up case & 0 & 0 & 0 \\
PWR & 580 & 1,750 & 2,870 \\
CANDU & 580 & 1,570 & 2,870 \\
Total & & & \\
\hline
\end{tabular}

Note: The year for PWRs sites to saturate their spent fuel storage capacities will be 2030 for the current burn-up case, while there will be no shortage for the extended burn-up case.

\section{ECONOMIC CONSIDERATIONS}

\section{Options for Spent Fuel Storage}

Through 2015, when pools are saturated, additional spent fuel would be stored on-site in dry-storage facilities. Thereafter, there are six alternative options.

Option 1: Dry storage at NPP sites

Option 1 employs on-site dry storage ${ }^{25}$ to provide additional storage capacity for AR spent fuel discharged from PWRs and CANDU reactors.

Option 2: Inter-site transshipment starting in $2016^{26}$

Option 2 commences intersite transshipment for AR spent fuel discharged from PWRs starting in 2016, while continuing on-site dry storage for fuel discharged from CANDU reactors.

Table 13: Cumulative additional storage capacity required in South Korea (low growth scenario with intersite transshipment).

\begin{tabular}{lrrr}
\hline Type & By 2010 (tHM) & By 2020 (tHM) & By 2030 (tHM) \\
\hline Current burn-up case & & & \\
PWR & 0 & 0 & 4,140 \\
CANDU & 1,950 & 5,510 & 8,070 \\
Total & 1,950 & 5,510 & 12,210 \\
Extended burn-up case & 0 & 0 & 2,170 \\
PWR & 580 & 2,310 & 3,150 \\
CANDU & 580 & 2,310 & 5,320 \\
Total & & \\
\hline
\end{tabular}

Note: PWRs sites will saturate their spent fuel storage capacities by 2023 for the current burnup case, and 2027 for the extended burn-up case. 
Option 3: AFR interim storage facility starting in 2016

Option 3 transports AR spent fuel discharged from PWRs and CANDU reactors to centralized AFR interim storage facility starting in 2016.

Option 4: Overseas storage starting in 2016

Option 4 sends AR spent fuel discharged from PWRs after 2016 overseas for storage until at least $2030,{ }^{27}$ while continuing on-site dry storage for fuel from CANDU reactors.

Option 5: Overseas reprocessing after $2016^{28}$

Option 5 sends all AR spent fuel discharged from PWRs starting in 2016 overseas to be stored for 10 years, after which period the fuel will be reprocessed and the separated plutonium fabricated into mixed oxide (MOX) fuel. The MOX fuel would then be sent back to South Korea and burned in PWRs. All fuel from CANDU reactors would continue to be stored on-site in dry-storage.

Option 6: Direct Use of spent PWR fuel In CANDU (DUPIC) ${ }^{29}$ fuel cycle after 2016

Option 6 commences the DUPIC fuel cycle for AR spent fuel discharged from PWRs after 2016. PWR spent fuel that exceeds the feed capacity of DUPIC fuel for CANDU reactors is not processed as DUPIC fuel and is maintained on-site in dry storage.

\section{Cost Analysis}

For each option, we consider only the costs incurred in managing spent fuel discharged after the pools are saturated. That is, the cumulative costs shown in Table 15 do not include the costs of pool management, including reracking. Also we do not consider costs for the process for disposal or treatment of the spent fuel subsequent to 2030. Cost estimates for all options are described in terms of undiscounted constant dollars (2001 U.S.\$) and discounted net present values (NPV). ${ }^{30}$ A 5\% and 10\% per annum discount rate is used for this purpose. All the evaluations are based on projections of spent fuel generation and additional spent fuel storage capacity for the reference scenario used in this study. The unit price assumptions for the component stages used in this study are summarized in Table 14.

Tables 15 and 16 show a comparison of additional cumulative costs for the six options, described in terms of undiscounted and discounted costs. The total discounted cost is calculated by spreading the constant dollar cash flows consistent with the time schedule, and then discounting these cash flows at 5\% and $10 \%$ discount rate. All costs are presented in 2001 U.S dollars. 
Table 14: Assumed unit prices (2001 U.S.\$).

\begin{tabular}{|c|c|c|c|c|}
\hline Component & $\begin{array}{l}\text { PWR } \mathrm{UO}_{2} \\
\text { fuel }\end{array}$ & $\begin{array}{l}\text { CANDU } \mathrm{UO}_{2} \\
\text { fuel }\end{array}$ & $\begin{array}{l}\text { MOX } \\
\text { fuel }\end{array}$ & $\begin{array}{l}\text { DUPIC } \\
\text { fuel }\end{array}$ \\
\hline $\begin{array}{l}\text { Uranium purchase }(\$ / \mathrm{kgU}) \\
\text { Conversion }(\$ / \mathrm{kgU}) \\
\text { Enrichment }(\$ / \mathrm{SWU}) \\
\text { Fabrication }(\$ / \mathrm{kgHM}) \\
\text { Transport }(\$ / \mathrm{kgHM}) \\
\text { Storage }(\$ / \mathrm{kgHM}) \\
\text { Reprocessing }(\$ / \mathrm{kgHM}) \\
\text { Overseas transport for PWR } \\
\text { Overseas transport for MOX } \\
\text { Overseas transport for VHLV } \\
\text { Storage for } \mathrm{VHLW}(\$ / \mathrm{kgHM}\end{array}$ & $\begin{array}{l}33.0^{a} \\
8.8^{b} \\
129.7^{a} \\
219.8^{b} \\
61.0^{c} \\
142.1^{d} \\
1,098.9^{b} \\
\mathrm{JO}_{2} \text { spent } \\
\text { fresh fuel } \\
* \text { ( } \$ / \mathrm{kgHM} \\
f \text { original }\end{array}$ & $\begin{array}{l}31.7^{a} \\
8.2^{b} \\
- \\
38.5^{a} \\
15.9^{c} \\
38.5^{a} \\
\bar{u} \\
/ \mathrm{kgHM}(\$ / \mathrm{kgHM})=26 \\
\text { ff original spe } \\
\text { ent fuel })=3\end{array}$ & $\begin{array}{l}- \\
- \\
1,648.4^{b} \\
57.9^{c} \\
142.1-184.7^{d} \\
- \\
=131.0^{e} \\
.9^{e} \\
\text { t fuel }=131.0 \\
.5-106.6^{d}\end{array}$ & $\begin{array}{l}- \\
- \\
613.2-3,000^{a} \\
57.9^{c} \\
135.7^{d} \\
-\end{array}$ \\
\hline
\end{tabular}

Note: All values in Table 14 are modified values reflecting the GDP deflation of the U.S. ${ }^{1}$

a 1996 values of prices of uranium purchase, enrichment, fabrication of CANDU $\mathrm{UO}_{2}$ fuel, fabrication of DUPIC fuel and storage of CANDU spent fuel were $30 \$ / \mathrm{kgU}, 118 \$ / \mathrm{SWU}$, $35 \$ / \mathrm{kgU}, 558 \$ / \mathrm{kgHM}$ and $35 \$ / \mathrm{kgHM}$, respectively. ${ }^{2}$ Due to the uncertainty of price of the DUPIC fuel fabrication, $3,000 \$ / \mathrm{kgHM}$ is assumed as maximum range of price. ${ }^{3}$

b1996 values of prices of uranium conversion, fabrication of PWR $\mathrm{UO}_{2}$ fuel, fabrication of MOX fuel and reprocessing were $8 \$ / \mathrm{kgU}, 200 \$ / \mathrm{kgU}, 1,500 \$ / \mathrm{kgHM}$ and $1,000 \$ / \mathrm{kgHM}$, respectively. ${ }^{4}$

C 1991 values of transport prices of PWR spent fuel and CANDU spent fuel were $50 \$ / \mathrm{kgHM}$ and $13 \$ / \mathrm{kgHM}$, respectively. ${ }^{5}$ Transport price of MOX spent fuel and DUPIC spent fuel is assumed to be that of PWR spent fuel. ${ }^{6}$

d 1989 values of storage prices of PWR spent fuel was $108 \$ / \mathrm{kgHM}^{7}{ }^{7}$ Storage price of MOX spent fuel is assumed to be 1 to 1.3 times that of the PWR spent fuel because of its higher heat output. ${ }^{8}$ Storage price of the DUPIC spent fuel is assumed to be that of PWR spent fuel. ${ }^{9}$ Storage price for vitrified high-level waste (VHLW) is assumed to be 0.25 to 0.75 times that for PWR $\mathrm{UO}_{2}$ spent fuel originated. ${ }^{10}$

e 1992 values of overseas transport prices of PWR UO, spent fuel, VHLW associated with the same amount of original spent fuel and MOX fresh fuel were $110 \$ / \mathrm{kgHM}, 110 \$ / \mathrm{kgHM}$ and $220 \$ / \mathrm{kgHM}$, respectively. ${ }^{11}$

1<http://www.bea.doc.gov/>, U.S. Department of Commerce, Bureau of Economic Analysis. ${ }^{2}$ Economic Assessment of New Technology of Nuclear Fuel Cycle, KAERI/RR-1831/97, KAERI, South Korea, June 1998 (Korean).

${ }^{3}$ Private communication, Professor Frank von Hippel, Center for Energy and Environmental Studies, Princeton University, March 1999.

${ }^{4} \mathrm{~K}$. A. Williams et al, A Comparative Assessment of the Economics of Plutonium Disposition Including Comparison with Other Nuclear Fuel Cycles, U.S. Department of Energy, CONF970613-1, May 1997.

${ }^{5}$ The Economics of the Nuclear Fuel Cycle, OECD/NEA, Paris, 1994.

${ }^{6}$ According to the reference at footnote 7, the same transport cost was used for PWR $\mathrm{UO}_{2}$ spent fuel and DUPIC spent fuel.

${ }^{7}$ Estimated cost ranges of AR storage costs using metal casks would appear to be $\$ 40,000$ $\$ 50,000$ for a PWR assembly, i.e., 87-108\$/kgHM, (1989 U.S. \$). E. R. Johnson, "Choosing At-Reactor Spent Fuel Storage Technologies," Proceedings of the International Topical Meeting on High Level Radioactive Waste Management, Las Vegas, Nevada, April 8-12, 1990, pp. 1030-1036.

${ }^{8}$ Private communication, Harold Feiveson, Center for Energy and Environmental Studies, Princeton University, March 1999. However, the MOX spent fuel is assumed to be stored in the pools of reactors until 2030.

${ }^{9}$ The reference at footnote 7 uses nearly the same (94\%) storage cost DUPIC spent fuel as for PWR $\mathrm{UO}_{2}$ spent fuel.

${ }^{10}$ Private communication, Harold Feiveson, Center for Energy and Environmental Studies, Princeton University, March 1999.

1 Overseas transportation between Europe and Japan, J. Takagi et al., Comprehensive Social Impact Assessment of MOX Use in Light Water Reactors, Citizens' Nuclear Information Center, November 1997. 


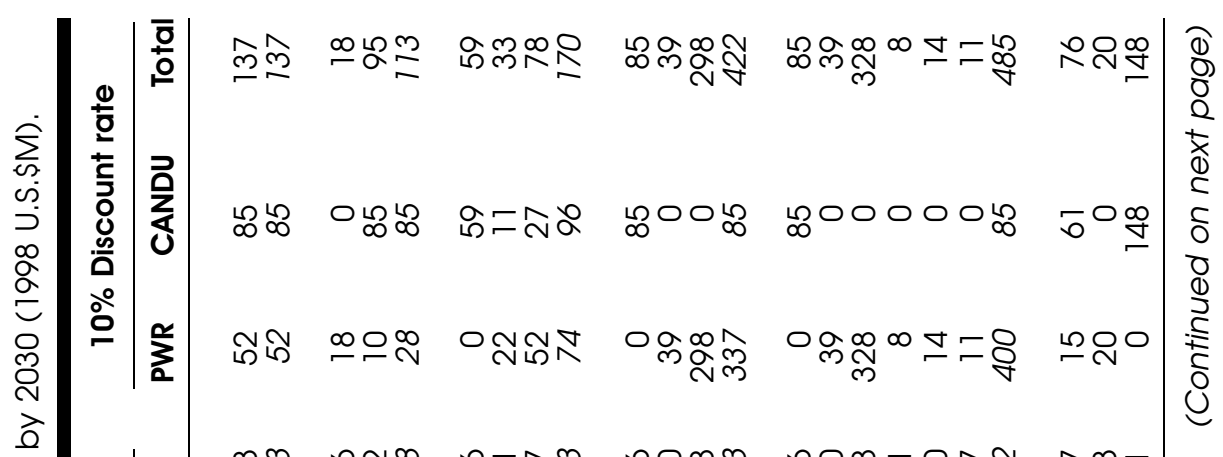

ర)

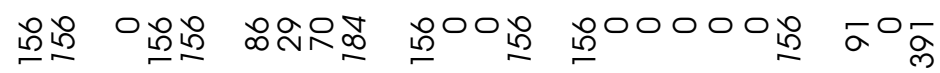

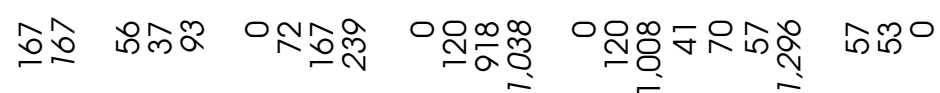

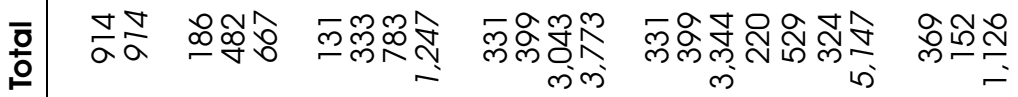

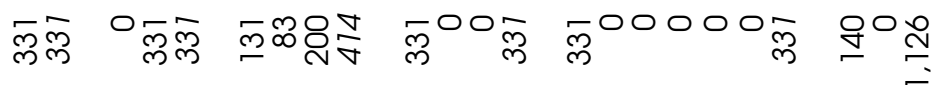

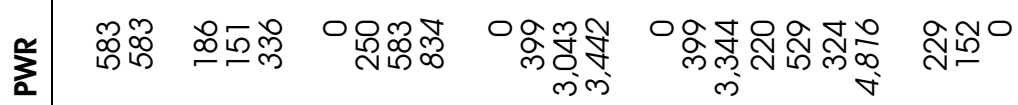

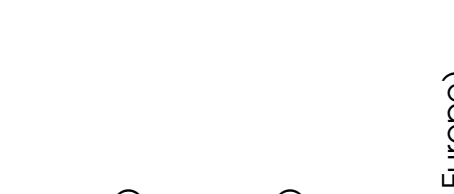

ब)
응
$\frac{0}{3}$

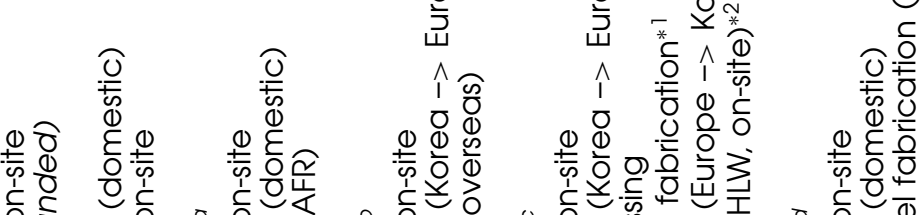

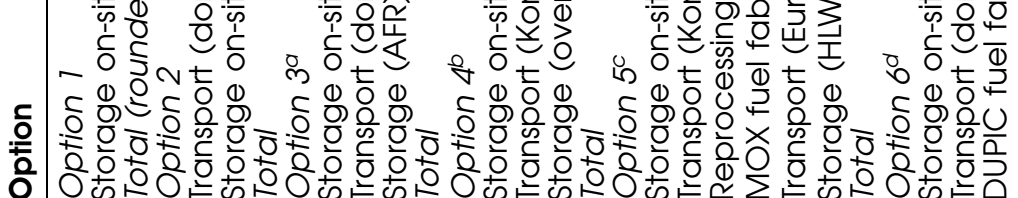




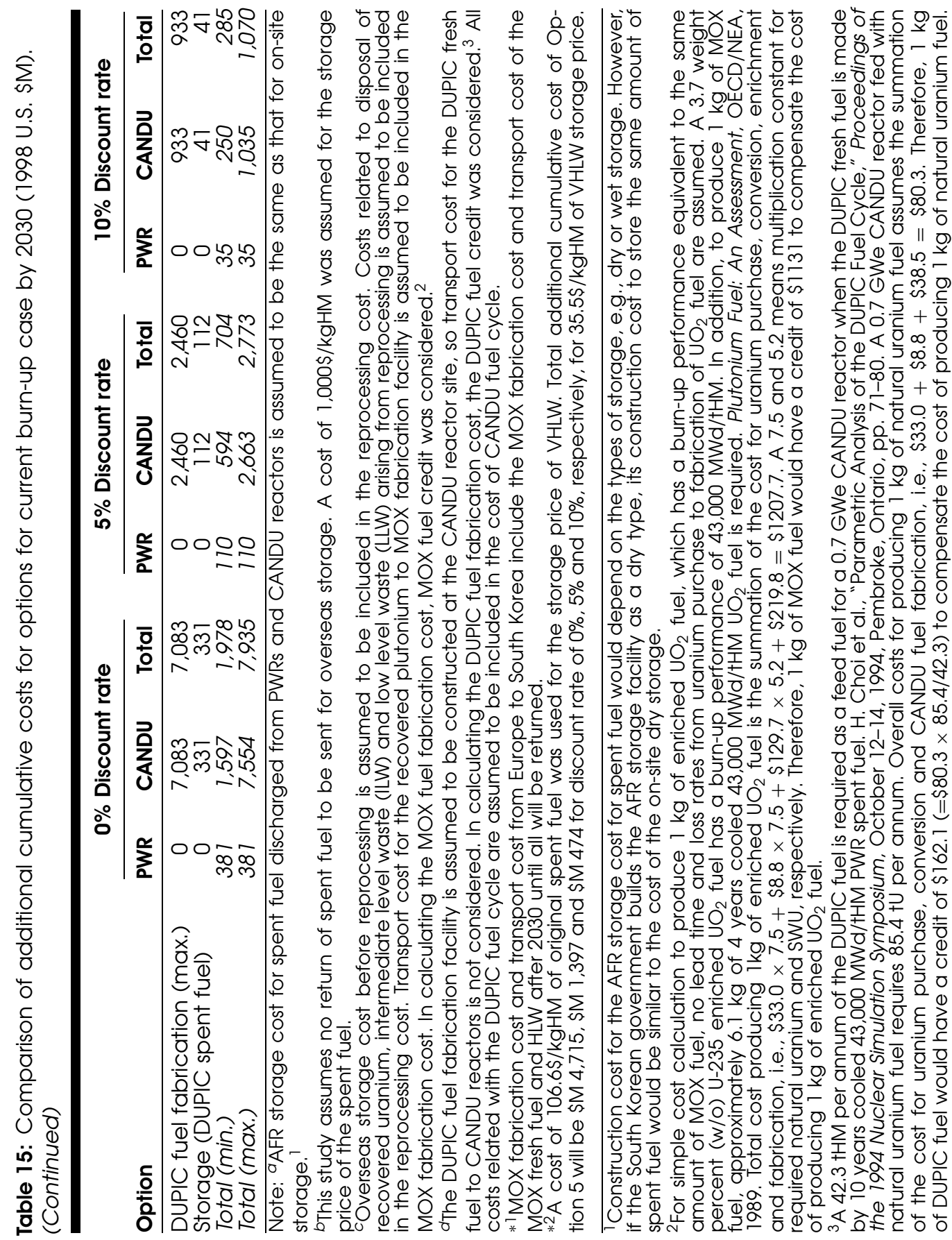




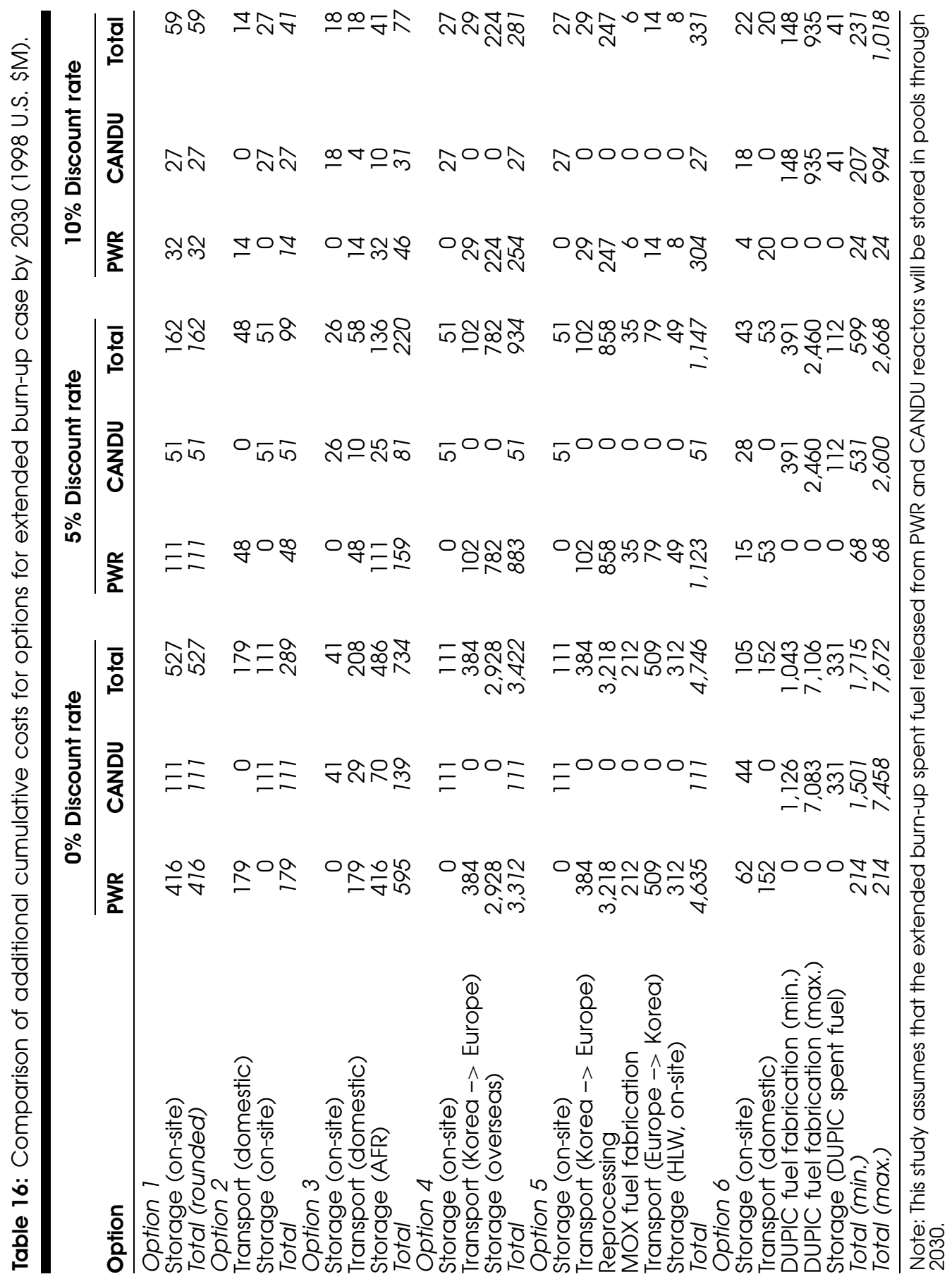


As indicated by Tables 15 and 16, Option 2 is the least expensive option. In terms of $5 \%$ discounted cost, the additional cumulative costs by 2030 for Option 2 are approximately $23 \%$ and $41 \%$ less than that for Option 1 and Option 3 , respectively, for current burn-up case, while approximately $39 \%$ and $55 \%$ less than that for Option 1 and Option 3, respectively, for extended burn-up case. This reduction is mainly due to the fact that Option 2 allows the maximum existing use of spent fuel storage. The other options are still more expensive, ranging about from 5 to 11 times the cost of Option 2 for current burn-up case, and about from 9 to 27 times the cost of Option 2 for extended burn-up case in terms of $5 \%$ discounted cost.

\section{INSTITUTIONAL RESTRICTIONS}

Options 2, 3, and 6 call for domestic shipment of spent fuel. For Option 2, the shipment would be 215 tHM per annum for PWR spent fuel from 2016 through 2030. It would be 238 tHM and 166 tHM per annum for PWR spent fuel for Option 3 and Option 6, respectively, for the reference scenario and with current burn-up. For Option 3, further transportation of $347 \mathrm{tHM}$ per annum is needed for CANDU spent fuel for the same time period.

Thus far, only a limited amount of spent fuel has been transported by KAERI, mostly for R\&D purposes. ${ }^{31}$ Two transshipments have been made between neighboring NPPs at the Kori site. For these purposes, Korean Standard Cask (KSC) series shipping casks have been developed and demonstrated to transport spent fuel safely. ${ }^{32}$ Domestic transport of spent fuel is regulated by the Ministry of Science and Technology (MOST), based on the South Korean Atomic Energy Act. ${ }^{33}$ The South Korean Atomic Energy Act permits such shipment if utilities can assure adequate safety of spent fuel under safeguards. The past safety record for spent fuel shipment in the U.S. and in other nations shows its feasibility. ${ }^{34}$

Domestic transportation of spent fuel could be provided by road, by rail, or by sea. The last is possible because all South Korean NPP sites are located along the seacoast. Whichever transport is used, the utility will have to provide appropriate measures for shipment of spent fuel, based on routing analysis that considers the overall risk to the public and consultation with affected local jurisdictions.

Options 4 and 5 call for overseas shipment of spent fuel. Such shipment will require consent of the U.S., Canada, and Australia, which are members of the Nuclear Suppliers Group (NSG) and supply uranium to South Korea. The South Korean government has bilateral nuclear cooperation agreements with

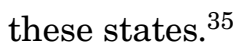


Options 5 and 6 call for reprocessing and recycling of PWR spent fuel, and will require the prior consent of the U.S., Canada, and Australia because of the same bilateral nuclear cooperation agreements. ${ }^{36}$

\section{CONCLUSIONS}

For the reference scenario and with current burn-up, if intersite transshipment between NPP sites is not allowed, estimated cumulative pool storage capacity will fall short of estimated spent fuel discharges through 2030 by approximately 3,900 MT for PWR spent fuel and 8,200 MT for CANDU spent fuel. The pools will be saturated at current sites between 2006 and 2022. Even with extended burn-up, the pool-saturation times will be delayed only about three years (oneyear for the Kori site). If intersite transshipment between NPP sites is allowed, even at current reactor burn-up, there will be no need for additional spent PWR fuel storage capacity until 2027. ${ }^{37}$ Economic evaluations for the six options considered in this study shows that intersite transshipment would be the most cost effective solution to the additional spent fuel storage problem in South Korea.

For the low growth scenario, in the case of no acquisition of further capacity of pools after 2016, if intersite transshipment between NPP sites is not allowed, pool-saturation times at NPP sites and cumulative additional storage capacity required will be the same as those for the reference scenario. If intersite transshipment between NPP sites is allowed, even at the low growth scenario, PWR sites will not become saturated until 2023 and 2027 for the current burn-up and extended burn-up cases, respectively.

Intersite transshipment appears the most straightforward and economic way to relieve the burden of additional spent PWR fuel storage requirements before final disposition if domestic transportation of spent fuel is implemented.

If intersite transshipment cannot be implemented due to concerns about transport of spent fuel or for other reasons, on-site dry storage would be the next most cost effective alternative.

\section{ACKNOWLEDGEMENTS}

The author would like to thank all those who provided information relating to this study. They are working in the following: Korea Atomic Energy Research Institute (KAERI), Korea Nuclear Fuel Company, Ltd. (KNFC), Korea Power Engineering Company (KOPEC), Seoul National University (SNU) and 
Technology Center for Nuclear Control (TCNC). Jungmin Kang would especially like to thank Professors Frank von Hippel and Harold A. Feiveson of Princeton University for their very useful comments and their assistance in bringing him to the Program on Science and Global Security (PS \& GS). The views and conclusions expressed in this article do not necessarily reflect the view of or any endorsement by these organizations or individuals within them.

\section{NOTES AND REFERENCES}

1. <http://www.most.go.kr/index-new.html> (Subtitle: Nuclear Statistics and General Status) Ministry of Science and Technology (MOST), South Korea (Korean).

2. Commencement of the underground repository is not expected in South Korea by 2030. White Book of Nuclear Power Generation, Ministry of Commerce, Industry and Energy (MOCIE), South Korea, July 1998 (Korean).

3. Construction of 3,000 metric tons (MT) of away-from reactor (AFR) spent fuel storage facility by 1997 was planned at the 221st South Korean Atomic Energy Commission (AEC) meeting in December 1988.

4. Centralized AFR interim storage facility for spent fuel that would be in operation in 2016. Type of spent fuel storage, e.g., wet storage or dry storage, will be determined until starting of construction in 2008. 249th South Korean AEC meeting, September 1998.

5. Spent fuel that would be discharged from PWRs of the Korean Peninsular Energy Development Organization (KEDO) program in North Korea is not considered in this study.

6. The Fourth Long-term Power Development Plan (1998-2015), MOCIE, South Korea, August 1998 (Korean).

7. The logistic curve has been used in the estimation of projections of electricity generation and installed nuclear capacity for the world through the year 2025. Nuclear Energy and Its Fuel Cycle: Prospects to 2025, OECD/NEA, Paris, 1987. The logistic curve fitting function for per capita electricity generation is specified as follows:

$$
E_{t}=\frac{E_{\infty}}{1+e^{-\left(a_{E}+b_{E} T\right)}},
$$

where:

$E_{t}=$ per capita electricity generation in year t,

$E_{\infty}=$ an assumed asymptote to which per capita generation tends,

$T=$ the time in years from the base year, and

$a_{E}$ and $b_{E}=$ parameters determined by following equation,

$$
a_{E}+b_{E} T=\log _{e} \frac{E_{t}}{E_{\infty}-E_{t}} .
$$

The derived parameters $a_{E}$ and $b_{E}$ are -0.2443 and 0.1177 , respectively.

8. Electricity Information 1996, International Energy Agency, OECD, 1997. 
9. Long-term Power Development Plan (1995-2010), MOCIE, South Korea, December 1995 (Korean).

10. Comprehensive Nuclear Energy Promotion Plan, MOST, South Korea, June 1997 (Korean).

11. S. H. Chang et al., "Korea looks beyond the next generation," Nuclear Engineering International, vol. 42, no. 511, 1997, pp. 12-16.

12. The First Power Supply Plan (2002-2015), MOCIE, South Korea, August 2002 (Korean).

13. C. S. Rim, "Korean Nuclear Fuel Program," Journal of Nuclear Science and Technology, vol. 35, no. 7, July 1998, pp. 467-472.

14. Private communication, Korea Nuclear Fuel Company, Ltd. (KNFC), South Korea, December 1998.

15. Ibid.

16. C. S. Rim, "Korean Nuclear Fuel Program," Journal of Nuclear Science and Technology, vol. 35, no. 7, July 1998, pp. 467-472.

17. K. M. Wasywich, Characteristics of Used CANDU Fuel Relevant to the Canadian Nuclear Fuel Waste Management Program, AECL-10463, COG-91-340, May 1993.

18. Private communication, Korea Nuclear Fuel Company, Ltd. (KNFC), South Korea, December 1998.

19. Y. E. Lee, M. J. Song, "Expansion of Spent Fuel Interim Storage Capability in Association with Back-End Fuel Cycle Policy in Korea," Proceedings of the Symposium on Waste Management 97, Tucson, U.S.A, 1997.

20. The annual spent nuclear fuel discharges is specified as following:

$$
S F_{t}=\frac{N C_{t} * 365 * C F_{t}}{T E_{t} * B U_{t}},
$$

where:

$S F_{t}=$ annual amount of spent nuclear fuel discharged in year t (tHM),

$N C_{t}=$ net nuclear capacity in year $\mathrm{t}(\mathrm{MWe})$,

$C F_{t}=$ capacity factor in year $\mathrm{t}$,

$T E_{t}=$ thermal to electrical efficiency in year $\mathrm{t}$, and

$B U_{t}=$ average discharge burn-up in year $\mathrm{t}(\mathrm{MWd} / \mathrm{tHM})$.

International Symposium on Nuclear Fuel Cycle and Reactor Strategy: Adjusting to New Reality, Key Issue Papers, International Atomic Energy Agency (IAEA), Vienna, 1997.

21. White Book of Nuclear Safety, Korea Institute of Nuclear Safety (KINS), South Korea, August 1998 (Korean).

22. Decay heat per unit mass from spent CANDU fuel of 7,100 MWd/tHM (cooled several years) is approximately one-tenth that of spent PWR fuel of 43,000 MWd/tHM (see Table 17 in the Appendix). In Table 6, the 12,350 tHM of spent CANDU fuel is equivalent to approximately 1,235 tHM of spent PWR fuel in decay heat generated, approximately $7 \%$ of the heat generated in cumulative PWR spent fuel discharges through 2030. 
23. However, this pool capacity could have more space if the spent fuel is stored as maximum storage density. Maximum storage density is defined by the maximum ratio of the area of storage cells to the area of pool, approximately $92 \%$ in PWR pools. J. Y. Jung, "Status of Onsite Spent Fuel Storage," Nuclear Industry, Korea Atomic Industrial Forum, November 1998, pp. 56-75 (Korean). $497.8 \mathrm{~cm}^{2}$ of pool is required for storage of a PWR spent fuel assembly because the cross section of PWR fuel assembly is $21.4 \times 21.4 \mathrm{~cm}^{2}$. J. W. Roddy et al., Physical and Decay Characteristics of Commercial LWR Spent Fuel, ORNL/TM-9591/V1, October 1985. The maximum number of PWR fuel assemblies per $1 \mathrm{~m}^{2}$ of pool is 20 , corresponding to $9.2 \mathrm{tHM}$ of spent fuel per square meter, considering the mass of 0.4614 tHM per PWR fuel assembly (see Table 6 ). The pools of Yonggwang 5 and 6 are $902 \mathrm{~cm}$ long, $743 \mathrm{~cm}$ wide and $1204 \mathrm{~cm}$ deep. Private communication, Korea Power Engineering Co., Inc (KOPEC), March 1999. Therefore, each pool of Yonggwang 5 and 6 could accomodate approximately 545 tHM of PWR spent fuel, with one full core storage capacity of $76.3 \mathrm{tHM}$, reserved for emergencies. Since the spent fuel storage pool is outside of the reactor containment, the size of the pools at future reactors would not be fixed by any other constraints, but economics of spent fuel storage.

24. When a reactor shuts down, there could be two options for the spent fuel, keeping the pools operating or moving all of the spent fuel into other storage facilities. However, at shutdown reactor sites, maintenance of pools following shutdown could lead to a significant cost burden to a utility. Operating one pool following shutdown has been estimated to cost approximately $\$ 3.7$ million (1989 U.S.\$) annually, based on the pool capacity of 595 MTHM. S. R. Rod, Cost Estimates of Operating Onsite Spent Fuel Pools after Final Reactor Shutdown, PNL-7778, August 1991. For dry storage, PWR spent fuel must first be cooled in pools for at least five years after it is removed from the reactor. Disposal and Storage of Spent Nuclear Fuel Finding the Right Balance. A Report to Congress and the Secretary of Energy, U.S. Department of Commerce, March 1996.

25. Dry storage is considered safer than pool storage. U.S. Nuclear Regulatory Commission, "Waste Confidence Decision Review. 55," Federal Register 38508, September 18, 1990.

26. According to the 249th meeting of the South Korean AEC in September 1998, all spent fuel discharged will be stored at their NPP sites until the commencement of centralized AFR interim storage facility. This is option 3 in this study.

27. British Nuclear Fuels Ltd. (BNFL) has proposed that overseas spent fuel could be stored at the Thermal Oxide Reprocessing Plant (THORP) at Sellafield in northern England for at least a decade, with reprocessing as an option after the end of the storage period. BNFL Inc. "Issues for BNFL's Congressional Staff Tour," August 1995. There are also proposals for overseas storage for spent fuel in Russia and Australia. According to one proposal, spent fuel from South Korea would be sent to Russia for storage with a charge of $700 \$ / \mathrm{kgHM}$, and possibly ultimate disposal with an additional charge of $1,000 \$ / \mathrm{kgHM}$. Reprocessing of the spent fuel might be an option for customers to select. Nuclear Fuel, February 22, 1999 and March 18, 1999.

28. The Joint Declaration of Denuclearization of the Korean Peninsula in 1991 commits Korea not to possess nuclear fuel reprocessing or enrichment facilities. Y. M. Choi, "Meaning and Organization of International Nuclear Non-Proliferation Regime," $\mathrm{Nu}$ clear Industry, KAIF, February 1998, pp. 50-56.

29. The basic idea of the DUPIC fuel cycle is to refabricate PWR spent fuel, which still contains approximately two times the fissile-material content of natural uranium 
into fuel for heavy water reactors, without separating plutonium. J. Kang, A. Suzuki, "Analysis on DUPIC Fuel Cycle in Aspect of Overall Radioactive Waste Management," Journal of Nuclear Fuel Cycle \& Environment, vol. 4, no. 1, 1997, pp. 19-27. The extra burn-up of the DUPIC fuel is due to the reactivity increase associated with the removal of some of the fission products, including almost all the cesium, during the DUPIC fuel fabrication process, and the additional reactivity gain resulting from the higher neutronics efficiency of heavy water. C. A. Bollmann et al., Environmental and Economic Performance of Direct Use of PWR Spent Fuel in CANDU Reactors, MIT-NFC-TR-014, Massachusetts Institute of Technology, June 1998. PWR spent fuel cooled for 10 years with 43,000 MWd/tHM burn-up produces fresh DUPIC fuel which, when spent, has a burn-up of 16,300 MWd/tHM, while 55,000 MWd/tHM PWR spent fuel gives 12,500 MWd/tHM in DUPIC spent fuel. At 12,500 MWd/tHM, approximately 55 tHM of the DUPIC spent fuel will be discharged annually, which is about $30 \%$ more, compared to approximately 42 tHM per annum for 16,300 MWd/tHM. H. Choi et al., "Parametric Analysis of the DUPIC Fuel Cycle," Proceedings of the 1994 Nuclear Simulation Symposium, October 12-14, 1994, Pembroke, Ontario, pp. 71-80. Higher burn-up of the PWR spent fuel is less attractive for the DUPIC fuel cycle.

30. (Discounted annual cash disbursement $)=($ undiscounted value $) /(1+($ discounted rate) $)^{n}$, where $\mathrm{n}=$ (the year of the expenditure)-2001. The NPV is an appropriate index of costs for comparing competing options because it reflects the time value of money.

31. There have been no urgent needs for a large amount of spent fuel transportation thus far.

32. International Cooperation at the OECD/NEA on the Geological Disposal of Radioactive Waste, OECD/NEA, Paris, 1998.

33. See article 86 of the South Korean Atomic Energy Act, article 235 of the Enforcement Decree of the Atomic Energy Act, and article 99 of Enforcement Regulations of the Atomic Energy Act.

34. More than 1,300 MT of spent fuel was transported in the U.S. during 1979-1995, and there were more than 7,000 rail shipments of spent fuel in Britain through 1986. There have been no accidents involving a release of radioactivity. M. Holt, Transportation of Spent Nuclear Fuel, Congressional Research Service Report for Congress 97-403, May 29, 1998.

35. The South Korean government has bilateral nuclear cooperation agreements with the U.S., Canada, and Australia in 1972, in 1976, and in 1979, respectively. $<\mathrm{http}: / / 203.230 .61 .4 />$ (Subtitle: Status of nuclear cooperation agreements, MOST, South Korea (Korean). According to the bilateral nuclear cooperation agreements with these nations, transfer of special material, produced through the use of material transferred to South Korea, to the other nations requires prior consent of the governments of those nations. K. S. Lee, "Concept and Major Factors of Nuclear Cooperation Agreement," Nuclear Industry, KAIF, February 1998, pp. 57-64 (Korean).

36. Altering in form or content of special material, produced through the use of material or technology transferred to South Korea, requires prior consent of the governments of the nations of origin, i.e. the U.S., Canada and Australia. K. S. Lee, "Concept and Major Factors of Nuclear Cooperation Agreement," Nuclear Industry, KAIF, February 1998, pp. 57-64 (Korean).

37. The present South Korean policy for the CANDU spent fuel is that the CANDU spent fuel will be stored in the dry storage at Wolsong site until it is finally disposed of 
in the geologic repository. Private communication, Professor C. S. Kang, Department of Nuclear Engineering, Seoul National University, South Korea, April 1999.

38. A. G. Croff, A User's Manual for the ORIGEN2 Computer Code, ORNL/TM-7175, July 1980.

\section{APPENDIX}

This appendix shows the decay heat, expressed in watts per MTHM, from several types of spent fuel and HLW as a function of cooling time, given in Table 17 and Figure 8. The decay heat was calculated by the ORIGEN2 code. ${ }^{38}$

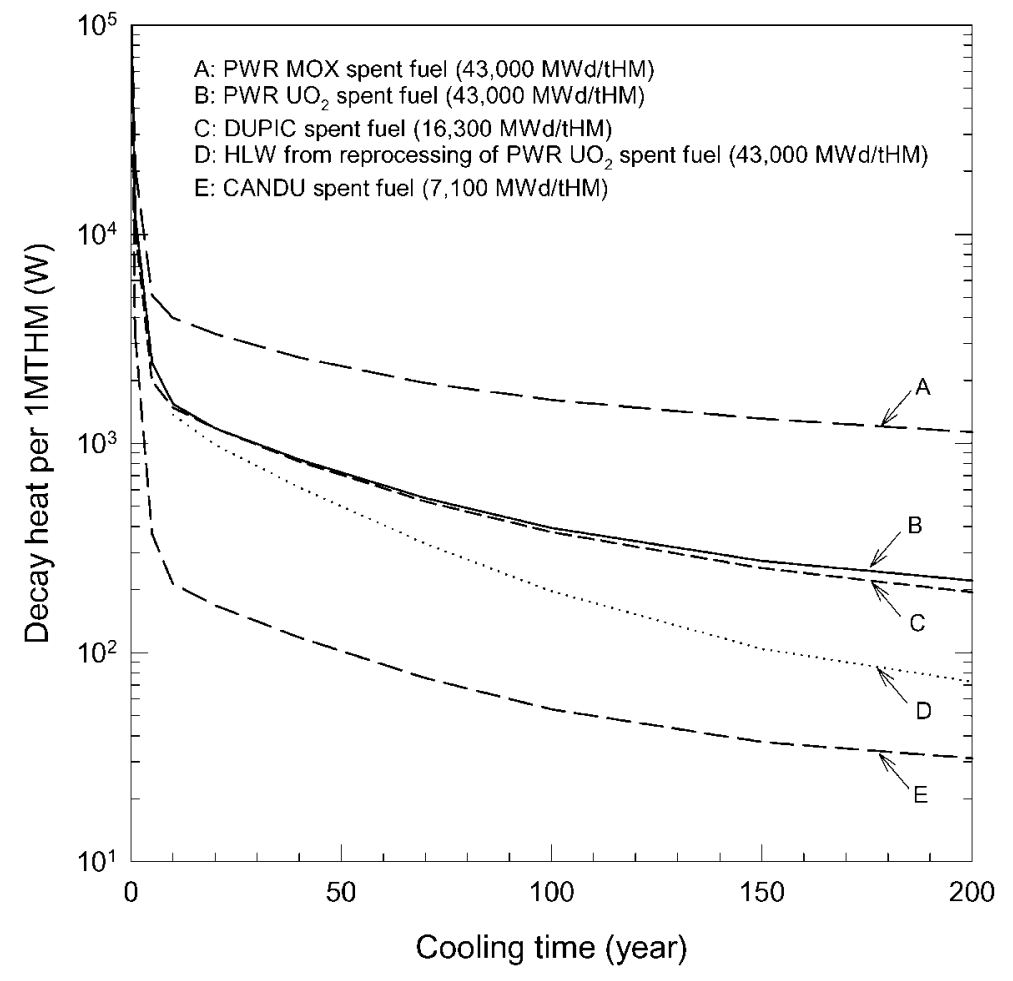

Figure 8: Decay heat from spent fuels and HLW as a function of cooling time. 
Table 17: Decay heat from spent fuels and HLW as a function of cooling time.

\begin{tabular}{|c|c|c|c|c|}
\hline Item & $\begin{array}{l}\text { At discharge } \\
\text { (W/tHM) }\end{array}$ & $\begin{array}{l}\text { 1-year } \\
\text { (W/tHM) }\end{array}$ & $\begin{array}{l}\text { 10-year } \\
\text { (W/tHM) }\end{array}$ & $\begin{array}{l}\text { 100-year } \\
\text { (W/tHM) }\end{array}$ \\
\hline \multicolumn{5}{|c|}{ PWR $\cup_{2}$ spent fuel ${ }^{a}$} \\
\hline Actinides & $1.22 \times 10^{5}$ & $8.87 \times 10^{2}$ & $3.65 \times 10^{2}$ & $2.73 \times 10^{2}$ \\
\hline Fission products & $2.00 \times 10^{6}$ & $1.16 \times 10^{4}$ & $1.17 \times 10^{3}$ & $1.21 \times 10^{2}$ \\
\hline Total & $2.12 \times 10^{6}$ & $1.24 \times 10^{4}$ & $1.54 \times 10^{3}$ & $3.94 \times 10^{2}$ \\
\hline \multicolumn{5}{|l|}{$\mathrm{HLW}^{\mathrm{b}}$} \\
\hline Actinides & N/A & N/A & $2.02 \times 10^{2}$ & $7.52 \times 10^{1}$ \\
\hline Fission products & N/A & N/A & $1.16 \times 10^{3}$ & $1.21 \times 10^{2}$ \\
\hline Total & N/A & N/A & $1.37 \times 10^{3}$ & $1.96 \times 10^{2}$ \\
\hline \multicolumn{5}{|c|}{ PWR MOX spent fuelc } \\
\hline Actinides & $1.09 \times 10^{5}$ & $8.37 \times 10^{3}$ & $3.06 \times 10^{3}$ & $1.52 \times 10^{3}$ \\
\hline Fission products & $1.88 \times 10^{6}$ & $1.26 \times 10^{4}$ & $9.18 \times 10^{2}$ & $9.25 \times 10^{1}$ \\
\hline Total & $1.99 \times 10^{6}$ & $2.10 \times 10^{4}$ & $3.98 \times 10^{3}$ & $1.67 \times 10^{3}$ \\
\hline \multicolumn{5}{|l|}{ CANDU spent fueld } \\
\hline Actinides & $1.05 \times 10^{5}$ & $2.63 \times 10^{1}$ & $2.32 \times 10^{1}$ & $3.25 \times 10^{1}$ \\
\hline Fission products & $1.36 \times 10^{6}$ & $3.31 \times 10^{3}$ & $1.90 \times 10^{2}$ & $2.09 \times 10^{1}$ \\
\hline Total & $1.47 \times 10^{5}$ & $3.33 \times 10^{3}$ & $2.13 \times 10^{2}$ & $5.34 \times 10^{1}$ \\
\hline \multicolumn{5}{|l|}{ DUPIC spent fuele } \\
\hline Actinides & $9.48 \times 10^{4}$ & $4.02 \times 10^{3}$ & $6.82 \times 10^{2}$ & $2.90 \times 10^{2}$ \\
\hline Fission products & $1.27 \times 10^{6}$ & $6.64 \times 10^{3}$ & $8.02 \times 10^{2}$ & $8.53 \times 10^{1}$ \\
\hline Total & $1.36 \times 10^{6}$ & $1.07 \times 10^{4}$ & $1.48 \times 10^{3}$ & $3.76 \times 10^{2}$ \\
\hline
\end{tabular}

a With burn-up of $43,000 \mathrm{MWd} / \mathrm{tHM}$.

bThe HLW is produced as a result of chemically reprocessing 10-year cooled 43,000 $\mathrm{MWd} / \mathrm{tHM}$ PWR $\mathrm{UO}_{2}$ spent fuel, containing all of what is in the spent fuel except the volatile elements and $99.5 \%$ of the uranium and plutonium. ${ }^{1}$

${ }^{c}$ The MOX fresh fuel is fabricated from plutonium recovered after 10 years cooling of 43,000 MWd/tHM PWR $\mathrm{UO}_{2}$ spent fuel using depleted uranium. ${ }^{2}$

dWith burn-up of 7,100 MWd/tHM.

eThe DUPIC fresh fuel is fabricated from 10 years cooled 43,000 MWd/tHM PWR $\mathrm{UO}_{2}$ spent fuel, and with a burn-up of 16,300 MWd/tHM when spent.

${ }^{1}$ A. G. Croff et al., Graphical and Tabular Summaries of Decay Characteristics for OnceThrough PWR, LMFBR, and FFTF Fuel Cycle Materials, ORNL/TM-8061, January 1982.

2Plutonium Fuel: An Assessment, OECD/NEA, Paris, 1989. 